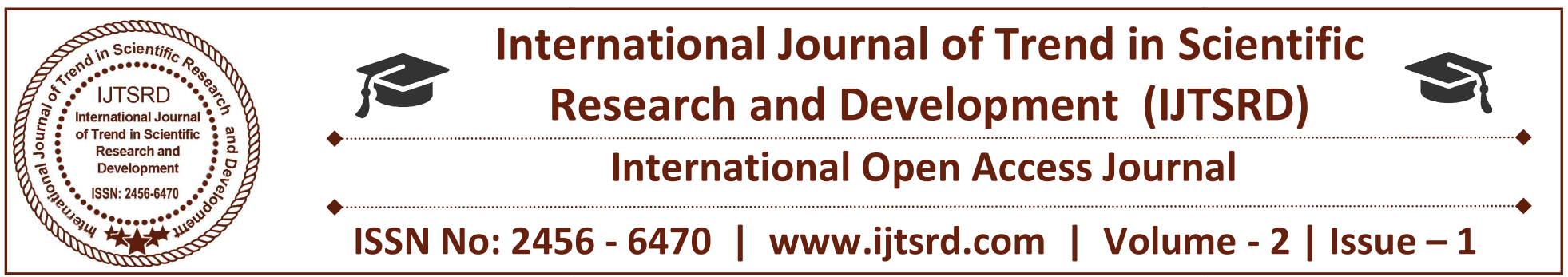

\title{
An Analytical Study based on a Virus Disease Infecting Datura stramonium $L$.
}

\author{
Ramneek Kaur \\ Research Scholar, Botany Deptt, \\ MONAD Universiy, Hapur
}

\author{
Dr. Prashant K Aryan \\ Head, Dept. of Botany, \\ MONAD University, Hapur
}

\section{ABSTRACT}

India has a great wealth of various naturally occurring plant drugs which have great potential pharmacological activities. Datura stramonium (D. stramonium) is one of the widely well known folklore medicinal herbs. Datura (Familiy-solanaceae), a genus of poisonous herbs, shrubs or small trees, is distributed throughout the tropical and warm temperate region of the world. The word 'Datura' is derived from the Arabic name 'Tatorah' or the Hindustani 'Dhatura'.This genus is represented by about 11 species (Datura ceratocaula, D. innoxia, D. metel, D. quercifolia, D. stramonium, D. tatula, D. discolor, D. wrightii, D. alba, D. fastuosa, D. ferox) of which D. innoxia, D. metel and D. stramonium are important drug plant whereas some are ornamenatals. (D. innoxia and D. metel). This paper is based on the analytical issues related with Datura.

Keywords: Datura, Scopolamine, herbs, virus etc.

\section{INTRODUCTION:}

Datura stramonium, known by the English names jimsonweed or Devil's snare, is a plant in the nightshade family. It is believed to have originated in Mexico but has now become naturalized in many other regions. Other common names for $D$. stramonium include thornapple and moon flower, and it has the Spanish name toloache. Other names for the plant include hell's bells, devil's trumpet, devil's weed, tolguacha, Jamestown weed, stinkweed, locoweed,

cucumber ${ }^{[8]}$ and Thornapple. All species of Datura contain powerful alkaloids which in sufficient quantities have the power to kill. The main alkaloids are Scopolamine, Hyoscyamin and Atropine. Scopolamine is intermediate in its central action between atropine and hyoscine. It causes less stimulation of the central nervous system than atropine and is a weaker sedative and hypnotic than hyoscine but is less powerful than atropine in its peripheral action. It's used to relieve fermon rigidity and excessive salivation in paralysis agitans. It is less reliable as a rapid sedative than hyoscine. Hyoscyamine is narcotic, antispasmodic and anodyne, and is used chiefly to relieve the spasm of the bronchioles in asthma. The leaves are applied to boils, sores and fish bites and the juice of the flowers is used for earache. The juice expressed from the fruit is applied to the scalp for curing dandruff and falling hair. There is some dispute regarding the regions of the origin of Datura species. Due to the presence of greatest variety of species in Mexico and Central America some found somewhere in the vicinity of the Caspian sea from where if spread south to Africa and east to Asia, eventually arriving in Europe supposedly with the gypsies, sometimes during the middle ages.

Datura has always played a significant role as "Culture plant" and evidence regarding their uses both in Asia and in New World date back atleast 3000 years. In both hemispheres Daturas were regarded as sacred and especially valued for their power to induce visionary dreams to see the future and to reveal the causes of diseases and misfortune. In Eurosia references to the uses and sacred status of Datura (mainly D.metel) can be found from the Caspian Sea to China. Especially in India, it found highly revered place of honour as one of the Shiva's sacred plants. According to the Vamana Purana it grew out of 
Shiva's chest and the Garuda Purana gives instruction for rituall offerings to Datura flowers, which should be made to Yogashwara (Shiva) on the $13^{\text {th }}$ day of waxing moon in January. Sadhus and yogis smoke the leaves and seeds mixed with Ganja, another plant sacred to Shiva. Besides, Kali worshippers also held Datura sacred. Nevertheless, despite its unpropitious reputation as a witches herb, it was valued and commonly employed for its medicinal properties throughout the world. Datura acts antispasmodically and has a particularly relaxant effect on the respiratory muscles. Furthermore, it suppresses glandular secretion, thus reducing the amount of mucous excreted through the lungs. The combination of these valuable properties makes it an ideal remedy for the treatment of Asthma. Throughout the middle ages Datura flowers were commonly sold for their aphrodisiac qualities all over central and southern Europe. They had the reputation of breaking down any resistance to sexual approaches.

\section{Datura Stramonium}

It is a very important ancient herb, having great religious importance. Its flower are believed to be associated with Lord Shiva. Ancient Hindu physicians regarded this herb as an intoxicant, with digestive, emitic and healing properties. Datura is infected by a number of pathogens such as Fungal (Roy et al., 1998), Bacterial (Kranz et al., 1977, Bashon and Okony 1986, Viczian et al., 1988, Stevenson et al., 2001, Gera et al., 2004) Nematode (Vau terin et al., 1995), Phytoplasma (Al Ani et al., 2001) and Viral (Biichen-Ormond., 2006, Steele \& Thomas., 2009).

The present investigation was taken up to characterize the virus causing mosaic disease in Datura stramonium.

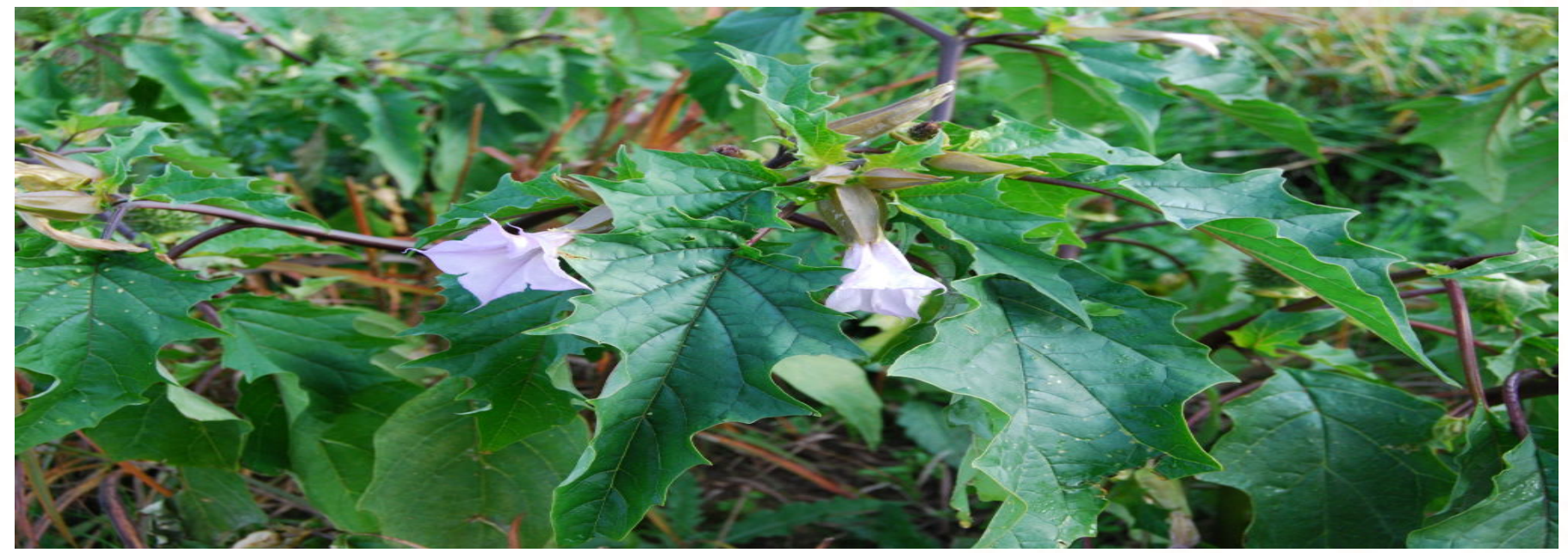

(Figure.1 D. stramonium)

\section{Existing Studies:}

The review of literature infecting Datura stramonium has revealed the infection of about 60 viruses on this important weed and medicinal plant but only 22 viruses have been recorded to cause natural infection in Datura.

2.1: Capoor and Verma : A mosaic disease of Datura alba was first described by Capoor and Verma in 1948 and they suggested the name distortion mosaic of Datura alba. The virus caused light and dark green mosaic accompanied by blister like patches of dark green portion on leaf lamina, distortion and reduction in leaf size. The plants were seldom dwarfed. The causal virus withstood heating for $10 \mathrm{~min}$. at $60^{\circ} \mathrm{C}$, retained infectivity at a dilution of 1 in 10,000 and after storage for 13 days at room temperature $\left(80^{\circ} \mathrm{F}\right)$. The virus also infected Nicotiana tabacum, Petunia sp. and Solanum tuberosum and produced local necrotic lesions on Phaseolus vulgaris, Vigna sinensis and Solanun melongena. The virus was also transmitted by Myzus persicae.

2.2: Salamon (1989): It recorded the natural occurrence of a new potyvirus (a strain of henbane mosaic virus) spontaneously infecting the thornapple (D. stramonium L.), in Hungary. Hiskias et al. (2001), studied biological characteristics of tomato mild virus a potyvirus isolated from tomato thorn apple in Ethiopia. The two isolates (246/94 and 277/94) from thornapple (Datura stramonmium) and tomato to ( $L$. 
lycopersicon) respectively, were characterized biologically and serologically and compared with local isolates of potato virus isolated from tomato and other viruses and isolates infecting vegetables. Both isolates of TMMV infected only 16 of 28 plants species inoculated by sap and induced indistinguishable symptoms. The most susceptible host were Datura metel, Datura stramonium and Nicotiana glutinosa L. However, these isolates differed from the PVY isolate infecting Datura spp. and Solanum demissum L., while Potato Virus Y isolate infected Chenopodium quinoa wild and Capsicum annuum L., isolate 277/94 was transmitted non persistently by Myzus persicae Sulz. from diseased tomato to virus free Datura stramonium, Datura metel L., Nicotiana glutinosa and tomato plants and from this back to virus-free test plants of each species purified particles isolate 277/94 contained a single protein species with a molecular weight of $39 \mathrm{KDa}$ in double antibody sandwich enzyme linked immunosorbent assay (DAS-ELISA) antiserum to isolate 277/94 reacted strongly with a Yemeni isolate of TMMV, (Y 90/7), but did not react with any other potyvirus. This clearly shows that the Yemeni and Ethiopian isolates of TMMV are similar serologically.

2.3: Bonifec et al. (2002), carried out a survey to detect characterization Tomato Yellow Leaf Curl Virus (TYLCV) and identify its reservoir weed host in six regions (Arusha, Morogoro, Dodoma, Iringa, Kilimonjaro and Dar se salaam) in Tanzania. Disease severity was scored on a scale of 0 to 4 .

2.4: Rakib et al. (2011), evaluated the efficacy of frog fruit (Lippia-nodiflora L.), Datura (Datura metel L.) and Thuja (Thuja orientalis L.) extracts for inducing systemic resistance against PYV common strain in potato plants. The alcoholic extract of the above plants were used as tuber dipping before cultivation or foliage spraying after germination. The PVYo multiplication in the plants was followed serologically by ELISA. Results showed that dipping the tubers in the extract at 1,2,3 g/1 for 24 hours, or spraying the foliage by the extracts at the same concentration exhibited a protection period to the plant against PVY infection up to one month in the presence of virus source with the vector Myzus persicae Sulz. Means of ELISA readings at $405 \mathrm{~nm}$ for samples from treated plants were found to be 0.11 and 0.125 for L. nodiflora extract X 0.13 and 0.12 for Datura metel extract 0.13 and 0.12 for $T$. orientalis extract for the three concentration and the two methods of application respectively, compared with 2.52 for untreated plants. No significant differences between the concentrations or between the methods of application on virus multiplication were observed.

\section{Structure of Datura stramonium:}

Datura stramonium is a foul-smelling, erect, annual, freely branching herb that forms a bush up to 60 to $150 \mathrm{~cm}$ ( 2 to $5 \mathrm{ft})$ tall. The root is long, thick, fibrous, and white. The stem is stout, erect, leafy, smooth, and pale yellow-green. The stem forks off repeatedly into branches, and each fork forms a leaf and a single, erect flower. The leaves are about 8 to $20 \mathrm{~cm}$ (3-8 in) long, smooth, toothed, soft, and irregularly undulated. ${ }^{[12]}$ The upper surface of the leaves is a darker green, and the bottom is a light green. The leaves have a bitter and nauseating taste, which is imparted to extracts of the herb, and remains even after the leaves have been dried.Datura stramonium generally flowers throughout the summer. The fragrant flowers are trumpet-shaped, white to creamy or violet, and 6 to $9 \mathrm{~cm}\left(2 \frac{1}{2}-3 \frac{1}{2}\right.$ in) long, and grow on short stems from either the axils of the leaves or the places where the branches fork. The calyx is long and tubular, swollen at the bottom, and sharply angled, surmounted by five sharp teeth. The corolla, which is folded and only partially open, is white, funnel-shaped, and has prominent ribs. The flowers open at night, emitting a pleasant fragrance, and are fed upon by nocturnal moths. The egg-shaped seed capsule is 3 to $8 \mathrm{~cm}$ (1-3 in) in diameter and either covered with spines or bald. At maturity, it splits into four chambers, each with dozens of small, black seeds. 


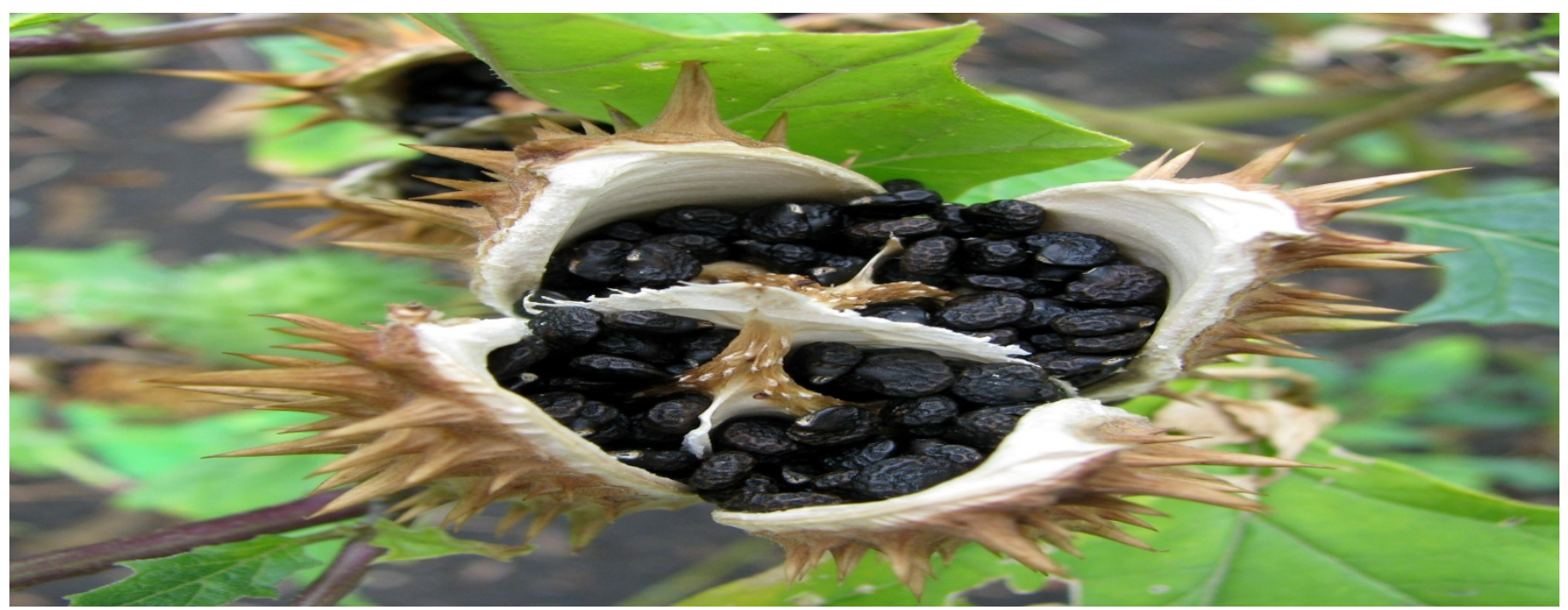

(Figure 2. D. stramonium Fruits)

\section{Pharmacological Properties:}

\section{1: Antiasthmatic activity}

D. stromonium in asthma treatment and possible effects on prenatal development was studied. Exposure of the foetus to D. stromonium when a mother use it for asthma, will cause a continuous release of acetylcholine, resulting in the desensitization of nicotinic receptors, this could ultimately result in permanent damage to the foetus. Therefore we conclude that this African herbal remedy should be used with caution during pregnancy.

\subsection{Anticholinergic activity}

The alkaloids found in D. stramonium, are organic esters used clinically as anticholinergic agents. Jimson weed has been reported as a drug of abuse and has been involved in the accidental poisoning of humans and animals. Symptoms of acute jimson weed poisoning included dryness of the mouth and extreme thirst, dryness of the skin, pupil dilation and impaired vision, urinary retention, rapid heartbeat, confusion, restlessness, hallucinations, and loss of consciousness. The anticholinergic syndrome results from the inhibition of central and peripheral muscarinic neurotransmission.

\subsection{Acaricidal, repellent and oviposition deterrent properties}

The ethanol extracts obtained from both leaf and seed in D. stromonium (Solanaceae) were investigated for acaricidal, repellent and oviposition deterrent properties against adult two-spotted spider mites ( $\mathrm{T}$. urticaeKoch) (Acari: Tetranychidae) under laboratory conditions. Leaf and seed extracts, which were applied in 167.25 and $145.75 \mathrm{~g} / \mathrm{L}$ concentrations, respectively (using a Petri leaf disc-spray tower method), caused $98 \%$ and $25 \%$ mortality among spider mite adults after $48 \mathrm{~h}$. These results suggest that $\mathrm{D}$. stramoniumextracts could be used to manage the two-spotted spider mite[21].

\subsection{Antimicrobial Activity}

The methanol extracts of D. stromonium and Datura inoxia showed activity against Gram positive bacteria in a dose dependent manner. Little or no antimicrobial activity was found against Escherichia coli and Psuedomonas aeruginosa[22]. The antimicrobial activity of combined crude ethanolic extract of D. stromonium, Terminalia arjuna and Withania somnifera in cup plate diffusion method for antibacterial and antifungal activity. The extracts were subjected to screening to detect potential antimicrobial activity against Staphylococcus aureus, Bacillus subtilus, Escherichia coli, Klebsiella pneumoniae, Micrococcus luteus and Candida albicans with compare Ciprofloxacin standard drug[23].

\subsection{Anticancer activity}

An integrated approach is needed to manage cancer using the growing body of knowledge gained through scientific developments. Thousands of herbal and traditional compounds are being screened worldwide 
to validate their use as anti-cancerous drugs. D. stromonium in therapeutic dose of $0.05-0.10 \mathrm{~g}$ was used to cure cancer. Likely unsafe produce vomiting, hypertension, loss of consciousness may lead to coma but may interact with anti-cholinergic drugs[24].

\subsection{Antiinflamatory activity}

Coriandrum sativum (C. sativum), D. stromonium and Azadirachta indica (A. indica) are traditionally used in treatment of inflammation. Ethanolic extracts of fruits of C. sativum, leaves of D. stromonium. Ethanolic extracts of fruits of C. sativum, leaves of D. stromonium and A. indica were subjected to preliminary screening for antiinflammatory activity in albino rats. All ethanolic extracts exhibited significant anti-inflammatory activity comparable to the standard drug diclofenac sodium against carrageenan induced rat paw edema method. Among these plant A. indica showed maximum anti-inflammatory activity per hour.

\section{Virus culture specifications:}

Single lesion culture form Chenopodium amaranticolor was used and the virus isolate was maintained on Datura stramonium by mechanical sap inoculation. Periodic check to ensure identity of the isolate was made on Datura stramonium, Chenopodium amaranticolor and other appropriate hosts. Chenopodium amaranticolor plants were used in all cases. Standard extract was used as inoculum for maintaining the culture.

\section{REFERENCES:}

1. Al-Ani RA, Al-Fadhil K.F, Al-Rawi F.A. AlShamri An. (2001). Serological relationship between suaeda withche's broom phytoplasma and those infecting some crops and weed Plants in Iraq. Arab journal of Plant Protection 191:5964.

2. Bashyan Y. and okony (1986). Internal and external infection of fruits and seeds of peppers by Xanthomonas Compestris PV. Canadian journal of Botany 64:2865-2871.

3. Boniface D. Kashina, Roberts B. M. \& Anatolia A. M. (2002) Reservoiv weed hosts of tomato yellow leaf curl Begomovirus from Tanzania Archives of Phytopathology and plant protection Volume 35, Issue 4, pp. 269-278.
4. Capoor, S. P. and Varma, P.M. (1948). A mosaic disease of Datura alba Nees. Curr. Sci. 17:151152.

5. Fry, C-R, Zimmerman, M.T, and Scott, -S-W. Scott. (2004). Occurrence of Colombian Datura Virus in the Terrestrial Orchids, Spiranthese cernua L. Journal of (Berlin). 152 (4) 200-203.

6. ICTVdB Management (2006). 00.029.0.03.020. Indian cassava mosaic virus. In :

7. ICTVdB- The Universal Virus Database, version 4. Biichen-Osmond. C. (Ed); Columbia University, New York, USA.

8. Gera, A. Maslenin, L, Rasner, -A., Zeidan, -M., Pivonia, -S. Weintraub, -P-G (2004). A new disease in Limonium hybrids. I molecular identification. Hort Science 39 (5):1056- 1059, 1053.

9. Hiskias, Yaynu D. -E. Lesemann and H. J. vetten (2001) Biological characteristic of Tomato Mild Mottle Virus a potyvirus isolated from tomato and thorn apple in Ethopia. Fedral Biological Research center for Agriculture and Forestry, Institute for Biochemistry and plant Virology, Messeweg 1112, 38104 Braunschweig, Germany.

10. Marcello, R. \& Giovanni P. M. (2005) Bulgarian Journal of Agricultural Science, 16 (No. 4), 412-421, Agricultural Academy.

11. Rakib, A. Al-Ani, Sabir N. H. Diwan, Mustafa A. Adhab (2011) Systemic resistance induced in potato virus against potato virus $\mathrm{Y}$ common strain by plant Extract in IRAQ. Advances in Environmental Biology, 5 (2) : 375-380.

12. Roy A-K, Prasad, M, -Nira Kumari, ChaurasiaH.K. (1988). Studies on association of mycoflora with drug-plants and aflatoxin Producing potentiality of Aspergillus Flavus Indian Phytopathalogy 41 (2): 261-262.

13. Salomon, -P. (1989) Novenyvedelem (Hungary). V. 25 (8) P. 337-347.

14. Steele and Thomas (2009) First report of Colombian Datura Virus from Australia.

15. Australian plant Disease Notes, 4, 108-109.

16. Stevenson, W.R., Loria, R., France, G.D. and Weingartner D.P. (2001). Compendium of Potato Disease 2nd Edition, APS Press. 
17. Vauterin, L., Hoste B Keners, K. and Swings, J. (1995). Reclassification of Xanthomonas International Journal of susternatic Bacteriology, 45:472-489.

18. Viczian- O, Sule- S and Gabarjanyi R (1998). Detection and identification of stolbur Phytoplasma in Hungary by PCR and RELP method. Acta Phytopathologica -et Entomologica -Hungarica. 33 (3-4): 255-260. 